\title{
Effects of filtration methods on the neutralization yield of crude marine fish oil
}

\author{
Vera Lúcia Viana do NASCIMENTO ${ }^{1 *}$, Victória Maura Silva BERMÚDEZ1, \\ André Luis Lima de OLIVEIRA ${ }^{1}$, Maurício Nunes KLEINBERG ${ }^{1}$, Rayane de Tasso Moreira RIBEIRO ${ }^{1}$, \\ Rosa Ferreira Araujo de ABREU ${ }^{2}$, José Osvaldo Beserra CARIOCA ${ }^{1}$
}

\begin{abstract}
The evaluation of filtration methods on the yield and oleochemicals characteristics on the crude fish oil from the soapstock of marine fish for purposes of nutrition has been conducted in this work. The analytical properties of the crude and the neutralized oil with three excesses of sodium hydroxide $(\mathrm{NaOH}, 20 \%, 40 \%$ and $60 \%)$ were carried out on two different ways with organza and the "glass wool". The neutralization of the oil brought about a notable improvement in the analytical properties of the oil. Thus, it leads to a high quality fish oil in terms of taste, colour, odours, shelf life and market value. Based on the improved characteristics of the oil, it could be suitable for applications in pharmaceutical and food industries.
\end{abstract}

Keywords: neutralization; fish oil; oleochemicals.

Pratical Application: The process of filtration of fish oil with different filters (organza and glass wool), which they differ in their composition and porosity. In this study, it was found that the filtering with organza filter has greater practical application, since it is easily available and lower cost, in addition to greater efficiency in the separation of sludge and fish oil.

\section{Introduction}

Fish oil is the lipid fraction extracted from fish and fish by-products. Presently, the production of fish oil is becoming more demanding as there is a sizeable and growing world market demand for high quality fish oils. Apart from its various uses as consumable oils, it is also appreciable in both pharmaceuticals and industries (Tacon \& Metian, 2009; Abdulkadir et al., 2010).

In general, marine fish, shrimp and mollusc oils are rich dietary sources of the $\mathrm{n}-3$ series of essential fatty acids (EFA); oils whose eicosapentaenoic acid (20:5n-3; EPA) and docosahexaenoic acid (22:6n-3; DHA) content constitutes over $20 \%$ of the total fatty acids include cod liver oil, cuttlefish liver oil, shortnecked clam oil, sardine oil, skipjack oil, shrimp head oil and squid liver oil (Chamberlain, 1993; Bandarra et al., 2006; Feltes et al., 2010).

Fish oil refining steps include extraction of crude oil, degumming, neutralization with sodium hydroxide, bleaching and deodorizing. The variation on the concentration of sodium hydroxide and other filtration parameters influence the addition of aqueous alkali solution for crude oil neutralization, which depends on the oil acidity to be reduced and maintain the oil's conservation state (Sathivel et al., 2003; O'Brien, 2009).

The fish oil is a commonly used ingredient in manufacturing shrimp feed because of high nutritional value. It provides the essential fatty acids, as well as enhancement of feed palatability (Tantikitti, 2014).
Thus, the purpose of this study was to evaluate the yield of neutralization on the crude fish oil from the soapstock of marine fish, commonly used in nutrition of shrimp, at different concentrations of alkali solution with sodium hydroxide, as well as the verification of the organza filter and "glass wool" filter alterations on the results of yield of neutralization.

\section{Materials and methods}

\subsection{Obtaining fish oil}

The experiment was conducted at the Processes and Products Development Laboratory (PPDL) at Federal University of Ceará (UFC). The raw material used on the experiment was special fish oil (about $0,5 \mathrm{~L}$ ), which is composed of viscera, heads and bones of fish of various species, obtained from Campestre industry and commerce of vegetal oil, located in municipality of São Bernardo do Campo, SP. The samples were stored on amber glass bottles under refrigeration $\left(5^{\circ} \mathrm{C}\right)$, until the moment of the analysis.

\subsection{Characterization and neutralization of fish oil}

The crude and neutralized fish oil were characterized by the following chemical and physical determinations: content of acidity (\% oleic acid), peroxide, acid, saponification values 
and yield of neutralization, according to the AOCS method (American Oil Chemists Society, 2002).

The neutralization consists on the elimination of acidic impurities, avoiding oil alterations (Martins, 2012). Caustic neutralization of crude fish oil was carried out at $18,6^{\circ}$ Baume and sodium hydroxide $(12,64 \% \mathrm{w} / \mathrm{w})$ with an excess amount of $20 \%, 40 \%$ and $60 \%$ (Table 1 ).

The process was performed under vacuum ( $260 \mathrm{mmHg}$ abs), and with vigorous stirring $(2500 \mathrm{rpm})$ at $60^{\circ} \mathrm{C}$ for $12 \mathrm{~min}$. After this time, stirring was weak for $6 \mathrm{~min}$ ( $300 \mathrm{rpm}$ ). Posteriorly, the mixture was decanted for $24 \mathrm{~h}$ at room temperature and after that the oil fraction was separated by filtration, centrifugation and washing (Figure 1).

\subsection{Filtration process of neutralized fish oil}

The filtration processes of neutralized fish oil were carried out on two different ways with organza (FO) and the "glass wool" (FW). For the filtration with organza fabric it was used only the $20 \%$ of excess, the neutralized oil was transferred to filler and placed under the FO and FW with three excesses of sodium hydroxide $(\mathrm{NaOH}, 20 \%, 40 \%$ and $60 \%)$.

\subsection{Statistical analysis}

The results for the yield and the oleochemical index were expressed as means \pm SEM $(n=6)$. Statistical evaluation was determined by analysis of variance (ANOVA) followed by

Table 1. Process conditions on the neutralization of crude fish oil.

\begin{tabular}{lccccc}
\hline $\mathrm{T}^{\circ} \mathrm{C}$ & $\begin{array}{c}\text { Excess } \\
(\%)\end{array}$ & $\begin{array}{c}\text { Weight } \\
\text { of NaOH } \\
(\%)\end{array}$ & $\begin{array}{c}\text { Mass of } \\
\text { alkali }(\mathrm{g})\end{array}$ & $\begin{array}{c}\text { Density } \\
(\mathrm{g} / \mathrm{L})\end{array}$ & $\begin{array}{c}\text { Volume } \\
(\mathrm{mL})\end{array}$ \\
\hline 60 & 20 & 12.64 & 4.56 & 1.142 & 4.0 \\
60 & 40 & 12.64 & 5.31 & 1.142 & 4.6 \\
60 & 60 & 12.64 & 6.07 & 1.142 & 5.3 \\
\hline
\end{tabular}

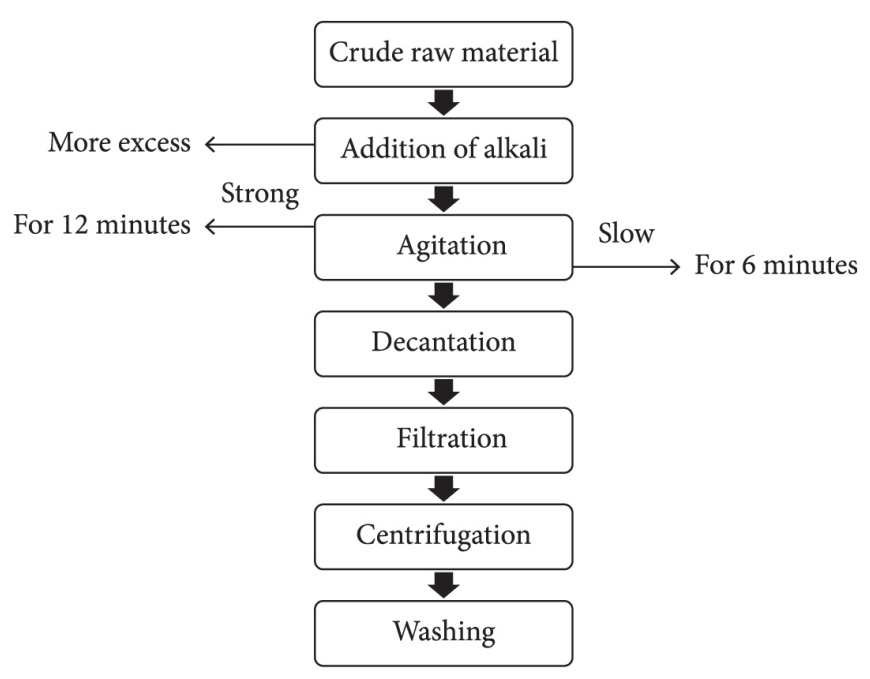

Figure 1. Flowchart of crude fish oil neutralization process. comparison with the Tukey test. Statistical significance was set at $5 \%$. The programs used to perform the statistical analysis were Microsoft Excel 2007 and GraphPad Prism 5.0.

\section{Results and discussion}

Fish oil was characterized along the following physico-chemical parameters: content of free fatty acids (\%), peroxide (mEq. $\left.\mathrm{kg}^{-1}\right)$, acid value $\left(\mathrm{mgNaOH} . \mathrm{g}^{-1}\right)$, saponification value and yield of neutralization, according to the AOCS method (American Oil Chemists Society, 2002), as shown in Table 2.

The amount of free fatty acids (FFA) in raw and neutralized fish oil were found to be $4,4 \pm 0,1 \%$, FO $(1,1 \pm 0,002 ; 2,9 \pm 0,2$; $1,9 \pm 0,05 \%)$ and FW $(1,4 \pm 0,11 ; 0,84 \pm 0,11 ; 0,58 \pm 0,005 \%)$ for excesses of $20 \%, 40 \%$ and $60 \%$ of $\mathrm{NaOH}$ analysed, which observed a reduction from that of crude oil. The percentages of free fatty acids (above 1,5\%) are the determination or indication of unsuitability of the lipid for edible purpose (Molla et al., 2007). Regarding the filtration of crude fish oil in both filters (organza and glass wool), these lipids might be suitable for edible purpose.

The acid values showed the effects of filtration method on the chemical properties, such as acid value was $5,4 \pm 0,13 \mathrm{mg}$. $\mathrm{NaOH} . \mathrm{g}^{-1}$ for the crude fish oil, while values after filtration process with FO $\left(1,1 \pm 0,002 ; 2,9 \pm 0,2 ; 1,9 \pm 0,05 \mathrm{mg} . \mathrm{NaOH} \cdot \mathrm{g}^{-1}\right)$ and FW $\left(1,4 \pm 0,11 ; 0,84 \pm 0,11 ; 0,58 \pm 0,005 \mathrm{mg} \mathrm{NaOH} . \mathrm{g}^{-1}\right)$ for excesses of $20 \%, 40 \%$ and $60 \%$ of $\mathrm{NaOH}$ evaluated, which shows a considerable reduction from that of crude oil. These results of acid values of crude and neutralized oil were lower in comparison to other fish oils, such as: Mormyrups deliciousus $\left(8,4 \mathrm{mg} \cdot \mathrm{NaOH} \cdot \mathrm{g}^{-1}\right)$, Bagrus docmac níger (7,8 mg.NaOH.g $\left.{ }^{-1}\right)$, Tilapia dagati (6,7 mg.NaOH.g ${ }^{-1}$ ) (Abdulkadir et al., 2010).

Young et al. (1993) has reported that peroxide value of crude fish oil was between 3 and 20 meq. $\mathrm{kg}^{-1}$. In this study, the peroxide values of the raw oil $\left(6,5 \pm 0,01\right.$ meq. $\left.\mathrm{kg}^{-1}\right), \mathrm{FO}$ $\left(15,7 \pm 0,06 ; 15,1 \pm 0,8 ; 17,1 \pm 0,82\right.$ meq. $\left.\mathrm{kg}^{-1}\right)$ and FW $(8,5 \pm 1,11$; $15,1 \pm 1,12 ; 11,1 \pm 1,18$ meq. $\mathrm{kg}^{-1}$ ) are well below acceptable limit of 20 meq. $\mathrm{kg}^{-1}$. This indicated that the fish oil extracted had low lipid oxidation rate (Pike, 1998).

Saponification is the process of breaking down a neutral fat into glycerol and fatty acids by alkali treatment. The saponification value (SV) of fish oil obtained in this study was lower $(158 \pm 0,42$ $\left.\mathrm{mg} . \mathrm{KOH} . \mathrm{g}^{-1}\right)$ than standard value for fish oil (180-200 mg.KOH.g $\mathrm{g}^{-1}$, given by AOCS (American Oil Chemists Society, 2002). In the filtration process occurred a reduction in SV with both filters (FO - 81,5 $\pm 0,6 ; 63,7 \pm 0,5 ; 70,5 \pm 0,6$ mg.KOH..$^{-1}$ nd FW - 89,4 $\pm 0,7$; $\left.92,4 \pm 0,9 ; 75,3 \pm 0,6 \mathrm{mg} \cdot \mathrm{KOH} \cdot \mathrm{g}^{-1}\right)$.

Bimbo \& Crowther (1991) reported that crude oil contains minor amount of non-triglyceride substances. Thus, it is possible that high SV was due to impurities present in crude fish oil. Additionally, higher saponification value may be contributed by the unsaponifiable matter present in the leaching waste materials such as sterols, glyceryl ethers, hydrocarbons, fatty alcohols and some minor quantities of pigments and vitamins.

The analysis of percentage yield of oil showed significant differences $(p<0,05)$ between the two forms of filtration with organza filter (FO) and "glass wool" filter (FW) in all excesses 
Table 2. Means $( \pm S D)$ of free fatty acids (FFA), acid, peroxide and saponification values and yield of neutralized fish oil in two filtration processes, with organza and glass wool filters, respectively.

\begin{tabular}{|c|c|c|c|c|c|c|c|}
\hline \multirow{3}{*}{ Oleochemicals index } & \multicolumn{7}{|c|}{ Fish oil } \\
\hline & $\mathrm{Raw}^{*}$ & & & & Neutralized $^{\star}$ & & \\
\hline & & $\mathrm{FO}-20 \%$ & $\mathrm{FO}-40 \%$ & FO - $60 \%$ & FW $-20 \%$ & FW $-40 \%$ & $\mathrm{FW}-60 \%$ \\
\hline FFA (\%) & $4.4^{\mathrm{a}} \pm 0.10$ & $0.9^{\mathrm{b}} \pm 0.001$ & $2.4^{\mathrm{b}} \pm 0.16$ & $1.5^{\mathrm{b}} \pm 0.04$ & $1.2^{\mathrm{b}} \pm 0.09$ & $0.69^{b} \pm 0.09$ & $0.47^{\mathrm{b}} \pm 0.004$ \\
\hline $\begin{array}{l}\text { Acidity value } \\
\left(\mathrm{mg} . \mathrm{NaOH} \cdot \mathrm{g}^{-1}\right)\end{array}$ & $5.4^{\mathrm{a}} \pm 0.13$ & $1.1^{\mathrm{b}} \pm 0.002$ & $2.9^{\mathrm{b}} \pm 0.2$ & $1.9^{\mathrm{b}} \pm 0.05$ & $1.4^{\mathrm{b}} \pm 0.11$ & $0.84^{\mathrm{b}} \pm 0.11$ & $0.58^{\mathrm{b}} \pm 0.005$ \\
\hline $\begin{array}{l}\text { Peroxide value } \\
(\text { meq.kg-1) }\end{array}$ & $6.5^{\mathrm{a}} \pm 0.01$ & $15.7^{\mathrm{a}} \pm 0.06$ & $15.1^{\mathrm{a}} \pm 0.83$ & $17.1^{a} \pm 0.82$ & $8.5^{\mathrm{a}} \pm 1.11$ & $15.1^{\mathrm{a}} \pm 1.12$ & $11.1^{\mathrm{a}} \pm 1.18$ \\
\hline $\begin{array}{l}\text { Saponification value } \\
\left(\mathrm{mg} \cdot \mathrm{KOH} \cdot \mathrm{g}^{-1}\right)\end{array}$ & $158^{\mathrm{a}} \pm 0.4$ & $81.5^{\mathrm{b}} \pm 0.6$ & $63.7^{\mathrm{b}} \pm 0.5$ & $70.5^{\mathrm{b}} \pm 0.6$ & $89.4^{\mathrm{b}} \pm 0.7$ & $92.4^{\mathrm{b}} \pm 0.9$ & $75.3^{b} \pm 0.6$ \\
\hline Yield of neutralization (\%) & - & $72.1^{\mathrm{a}} \pm 4.4$ & $69^{\mathrm{a}} \pm 0.2$ & $72^{\mathrm{a}} \pm 0.5$ & $50^{\mathrm{b}} \pm 9.93$ & $33.4^{b} \pm 9.01$ & $40.1^{\mathrm{b}} \pm 0.69$ \\
\hline
\end{tabular}

${ }^{\star}$ Means followed by the same letter in the lines don't differ significantly, according to Tukey's test $(\mathrm{p}<0.05)$.

of $\mathrm{NaOH}$. The oil yield values of FO $(72,1 \% ; 69 \% ; 72 \%)$ were higher than that for the filtration with FW (50\%; 33,4\%; 40,1\%), respectively.

\section{Conclusions}

In conclusion, this study demonstrated the reduction in free fatty acids, acidity and saponification values of crude for neutralized fish oil from the soapstock of marine fish, while the peroxide value was lower in crude fish oil, compared to the neutralized oil. The reduction in acidity observed in both treatment filters (FO and FW) in different concentrations of sodium hydroxide indicated improvement in the quality of treated oil after bleach required for shrimp nutrition.

\section{References}

Abdulkadir, M., Abubakar, G. I., \& Mohammed, A. (2010). Production and characterization of oil from fishes. Journal of Engineering and Applied Sciences, 5(7), 769-776.

American Oil Chemists Society - AOCS. (2002). Official Methods and Recommended Pratices of the American Oil Chemists' Society. 5th ed. Washington.

Bandarra, M., Nunes, M. L., Andrade, A. M., Prates, J. A. M., Pereira, S., Monteiro, M., Rema, P., \& Valente, L. M. P. (2006). Effect ofdietary conjugated linoleic acid on muscle, liver and visceral lipid deposition in rainbow trout juveniles (Oncorhynchus mykiss). Aquaculture, 254(14), 496-505. http://dx.doi.org/10.1016/j.aquaculture.2005.10.034.

Bimbo, A. P., \& Crowther, J. B. (1991). Fish oil: processing beyond crude oil. INFOFISH International, 6(91), 20-25.

Chamberlain, G. W. (1993). Aquaculture trends and feed projections. World Aquaculture, 24, 19-29.
Feltes, M. M. C., Correia, J. F. G., Beirão, L. H., Block, J. M., Ninow, J. L., \& Spiller, V. R. (2010). Alternativas para a agregação de valor aos resíduos da industrialização de peixe. Revista Brasileira de Engenharia Agrícola e Ambiental, 14(6), 669-677. http://dx.doi. org/10.1590/S1415-43662010000600014.

Martins, G. I. (2012). Potencial de extração de óleo de peixe para produção de biodiesel (Dissertação de mestrado). Universidade Estadual do Oeste do Paraná, Cascavel.

Molla, A. H., Camellia, S., Ahsan, M. S., Talukder, S. M., \& Alam, M. T. (2007). Physico chemical and microbiological investigation of the lipid from Bangladeshi fresh water fish Mystus vittatus. University Journal of Zoology, 26, 21-25.

O'Brien, R. D. (2009). Fats and oils: formulating and processing for applications (3rd ed.). Boca Raton: CRC Press.

Pike, I. (1998). Future supplies of fishmeal and fish oil: quality requirements for aquaculture with particular reference to shrimp. In Turret Group, International Aquafeed Directory \& Buyers' Guide (pp. 39-49). Uxbridge: Turret RAI plc.

Sathivel, S., Prinyawiwatkul, W., Negulescu, I. I., King, J. M., \& Basnayake, B. F. A. (2003). Thermal degradation of fatty acids and catfish and menhaden oils at different purification steps. Journal of the American Oil Chemists'Society, 80(11), 1131-1134. http://dx.doi.org/10.1007/ s11746-003-0831-9.

Tacon, A. G., \& Metian, M. (2009). Fishing for feed or fishing for food: increasing global competition for small pelagic forage fish. Ambio, 38(6), 294-302. http://dx.doi.org/10.1579/08-A-574.1. PMid:19860152

Tantikitti, C. (2014). Feed palatability and the alternative protein sources in shrimp feed. Songklanakarin Journal of Science and Technology, 36(1), 51-55.

Young, S. L., Sarda, X., \& Rosenberg, M. (1993). Microencapsulating properties of whey proteins. 2. Combination of whey proteins with carbohydrates. Journal of Dairy Science, 76, 2878-2885. 